\title{
JOURNAL.RU
}

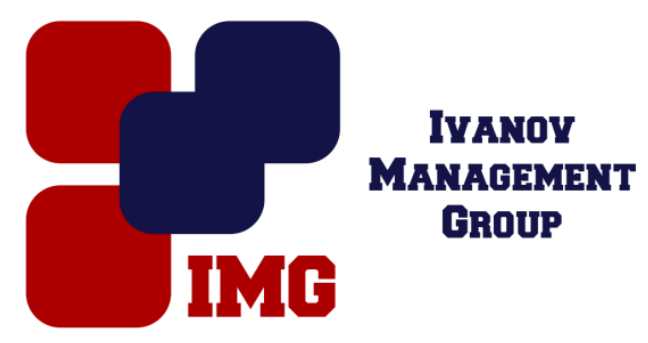

Басиев С.С., Джиоева Ц.Г., Плиева 3.Я., Басиева А.С., Царикаев 3.А.

Горский государственный аграрный университет Владикавказ, Россия

doi: 10.18411/lj-30-06-2017-49

idsp 000001:1j-30-06-2017-49

\section{Роль зеленых удобрений в семеноводстве картофеля}

\section{Аннотация}

Выявлена продуктивность и качество семенных и продовольственных клубней перспективных, районированных и новых сортов картофеля зарубежной и отечественной селекции в зависимости от экологических условий их выращивания и применения сидеральных культур.

Ключевые слова: картофель, семеноводство, сидераты.

В настоящее время вопросами применения зеленых удобрений занимаются научные учреждения, которые рекомендуют для использования на сидерацию в самостоятельных и промежуточных посевах большой набор культур: из бобовых - многолетний и однолетний люпин, сераделлу, донник, озимую и яровую вику, горох посевной и полевой, астрагал, чину, клевер, чечевицу, эспарцет, сою; из злаковых - озимую рожь, райграс однолетний и многолетний; из крестоцветных - горчицу, озимый и яровой рапс, озимую сурепицу, масличную редьку и др. Разлагаясь и поставляя в почву не гумифицированное органическое вещество, сидеральные культуры обогащают пахотный слой лабильными формами органического вещества. Зеленые удобрения улучшают агрегатный состав почвы и повышают водопрочность ее структуры $[1,2,3,4]$.

Для изучения сидеральных культур в биологическом земледелии закладывали опыт с 8 сортами картофеля (Волжанин, Владикавказский, Предгорный, Невский, Удача, Жуковский ранний, Романо и Сантэ) с использованием сидеральных культур: горчицы, редьки масличной и рапса на 
фоне N30P30K30. Экспериментальную работу проводили в 2005-2009 гг. на бурых лесных оподзоленных почвах Юго-Осетинской республики. Общая площадь делянки - 72,0 м2, учетная - 60,0 м2. Размещение вариантов рендомизированное. Повторность опыта - четырехкратная. Предшественник сидеральные культуры. Глубина посадки 8-10 см. Посадку проводили клубнями средней фракции (60-65 г) густотой 48,0 тыс. клубней на 1 га.

Все учеты и наблюдения проводили по методикам ВНИИКХ (1967; 1994; 2008; 2010; 2012), ВИР (2010) и Доспехова Б.А. (1985) [5].

Многочисленные исследования показали тесную взаимосвязь количества органического вещества, оставляемого предшествующей культурой, с содержанием агрономически ценной структурой. По многолетним травам количество агрегатов $0,25 \ldots 10$ мм увеличилось по сравнению с повторным посевом кукурузы на зерно на 9,5\%, по озимому рапсу - на 5,8\%, а на сидеральном посеве озимого рапса - на 19,2\%. Средняя плотность почвы по многолетним травам была в пределах от 1,06 до 1,16, при сидерации - 1,05-1,19, тогда как на контроле 1,08-1,21 г/см3.

Одним из основных показателей ценности сидеральных культур, влияющих на плодородие почвы, является масса органического вещества, накопленного в наземных и подземных органах растений ко времени запашки. Наши исследования показали, что она сильно варьировала в зависимости от возделываемой культуры и погодных условий. В среднем за несколько лет исследований больше органического вещества было накоплено $(7,97 ; 6,64 ; 6,13$ т/га) такими культурами, как рапс, редька масличная и горчица соответственно.

Данные наших исследований свидетельствуют, что сидеральные культуры оказывают существенное влияние на урожай клубней картофеля, максимальный показатель которого отмечен по всем сортам на варианте с использованием горчицы на сидерат с применением фона удобрений. Высокий урожай накопили сорта Владикавказский - 30,9 т/га, Удача - 29,6 т/га, Жуковский ранний 28,4 т/га.

Сидеральные культуры способствуют не только накоплению органических остатков в почве, её оструктуриванию, росту урожайности, но и увеличению крахмалистости и содержанию сухих веществ в клубнях различных сортов картофеля (на 0,4-3,4\%) с максимумом по сорту Предгорный. Довольно высокие показатели отмечены и по сортам Романо, Сантэ и Владикавказский. 


\section{Выводы}

1. Максимальные показатели по разложению надземной биомассы и корневых остатков отмечено на варианте, где картофель использовался в качестве монокультуры (78\%), минимальные - при запашке редьки масличной $(75 \%)$.

2. Выявлена эффективность использования сидеральных культур, повышающих содержание в почве минеральных веществ: азота, фосфора, калия, - и, как следствие, позволяющих увеличить массу клубней картофеля в пределах 5-10 т/га.

$* * *$

1. Басиев, С.С. Сидеральные культуры - повышение плодородия почвы и урожая картофеля / С.С. Басиев // Земледелие. - №1 - 2008. - С. 33.

2. Басиева, Л.Ж. Влияние различных звеньев севооборота на плодородие и продуктивность выщелоченного чернозема с близким залеганием галечника / Л.Ж. Басиева // Автореферат на соискание ученой степени кандидата сельскохозяйственных наук. - Владикавказ, 2000. - 22 с.

3. Доева, Л.Ю. Влияние сидерации, внесения соломы и азотных удобрений на урожай клубней картофеля / Доева Л.Ю., Бзиков М.А., Мамиев Д.М. // Иформационный листок СО ЦНТИ. - №99. - 1999.

4. Kumar, M. Influence of potato cultivars and $\mathrm{N}$ leveets on contribution of organic amendments to N nutrition / Kumar M., Trehan S.P. // J.Indian Potato Assn. - 2012. Vol. 39. - N. 2. - P. 133-144.

5. Доспехов, Б.А. Методика полевого опыта / Б.А. Доспехов. - М., 1985. - 352 с. 